\title{
СРАВНИТЕЛЬНЫЙ АНАЛИЗ ПРИМЕНЕНИЯ УПРОЩЕННОЙ СИСТЕМЫ НАЛОГООБЛОЖЕНИЯ НА ПРИМЕРЕ РОССИЙСКОЙ ФЕДЕРАЦИИ И РЕСПУБЛИКИ КАЗАХСТАН
}

\author{
(C) 2020 Петров Александр Михайлович \\ доктор экономических наук, профессор Департамента учета, анализа и аудита \\ Финансовый университет при Правительстве Российской Федерации, Россия, Москва \\ E-mail:palmi@inbox.ru
}

Долгие годы Россия и Казахстан являются не только соседями, но и союзниками, партнерами и добрыми друзьями. Эти дружеские отношения начались более 28 лет тому назад, когда и был подписан «Договор о дружбе, сотрудничестве и взаимной помощи» [1]. Этим двум странам вместе удалось сделать очень многое, поэтому можно с уверенностью сказать, что это сотрудничество развивается по всем направлениям и связано социальными, политическими, экономическими и культурными связями. И нужно добавить, что эти отношения постоянно развиваются. В статье проводится сравнение действующих упрощенных систем налогообложения Казахстана и России.

Ключевые слова: бухгалтерский учет, отчетность, упрощенная система налогообложения, Казахстан, Россия

Много общего и много различий можно найти, сравнивая Казахстан и Россию в ведении финансового, налогового и управленческого учета. Важную роль в странах с развитой экономикой играет малый и средний бизнес. Данный бизнес набирает большие обороты и своей массовостью создает социально-экономический климат во всей стране. Этот бизнес является как производителем, так и потребителем разных товаров и услуг. Он является важным звеном функционирования всей экономики в целом и дополняет крупный бизнес. Для малого и среднего бизнеса почти во всех странах с развитой экономикой принят особый (упрощенный) режим налогообложения. Проведем сравнение действующих упрощенных систем налогообложения Казахстана и России.

Упрощенная система налогообложения - это специальный налоговый режим, позволяющий снизить налоговую нагрузку на субъекты малого и среднего бизнеса, в частности из-за экономии на НДС, приводит к упрощению ведения налогового и бухгалтерского учета для этих субъектов.

Налогоплательщиками являются организации и индивидуальные предприниматели, применяющие упрощенную систему налогообложения по установленному законом порядку. Проще всего воспользоваться УСН с момента регистрации юридического лица и индивидуального предпринимателя. На ранних этапах бизнеса это очень облегчает работу компании, так как является своеобразной раскруткой фирмы для крупного бизнеса. Если же действующая организация или индивидуальный предприниматель переходит на упрощенку, то заявление подается в налоговый орган по месту нахождения не позднее 31 декабря календарного года, предшествующему календарному году, с которого они начинают применять УСН.

В России упрощенная система налогообложения впервые была введена с 29 декабря 1995 г. [2]. После этого вносились многие изменения и корректировки, а 1 января 2003 года УСН была модернизирована и стала применяться на всей территории Российской Федерации. При применении УСН организации освобождаются от таких налогов, как налог на прибыль, налог на имущество и освобождаются от уплаты налога на добавленную стоимость, за исключением НДС, установленного правилами НК РФ. Условия, которые необходимы для применения УСН в России - доход от реализации в течение года с момента подачи заявления на переход УСН составляет не более 150 млн. рублей, численность работников предприятия не должна превышать 100 человек. Нужно обязательно подавать заявление на переход специального налогового режима в налоговый орган. Так же по действующему законодательству РФ не вправе применять УСН банки, ломбарды, страховщики, дочерние организации и филиалы, нотариусы и т.д. Фирма добровольно переходит на УСН, 
главное соблюдать все правила и ограничения, установленные законодательством и прописанные налоговым кодексом РФ. Для прекращения применения УСН или переходе на другой режим, фирма должна уведомить налоговый орган, подав заявление не позднее 15 календарных дней по истечении отчетного периода или же при не соответствии требованиям УСН. Объектом налогообложения являются доходы и доходы, уменьшенные на величину расходов.

Так же для индивидуальных предпринимателей существует следующий вид УСН: патент вид налога только для ИП. Сумма налога в нем производится, как аванс, а в подтверждение уплаты налоговой инспекцией предоставляется документ (патент). При применении патентного режима налогообложения количество работников должно быть не более 15 человек, а доход не превышать 60 млн. рублей. Объектом налогообложения у патента является возможный к получению годовой доход индивидуального предпринимателя, который соответствует виду предпринимательской деятельности, соответствующий закону РФ. Облагается патент по ставке 6\%. В отличие от Казахстана, в России патент можно сочетать с любым видом налогообложения. Для того, чтобы начать использовать патентную систему в налоговую инспекцию подается заявление, не позднее, чем за 10 дней до начала применения этого спецрежима. Патент можно купить на срок от 1 до 12 месяцев, в зависимости от ситуации. Стоимость патента рассчитывается налоговым органом. Уплаченная сумма по патенту не возвращается, даже если деятельность индивидуального предпринимателя прекратилась раньше срока. При переходе с патентного на любой другой режим, то его применение разрешается только через 3 года.

В Казахстане иная ситуация, специальный налоговый режим стал применяться позднее на основе упрощенной декларации. Итак, применяют его индивидуальные предприниматели, доход которых за налоговый период составляет 1400-кратный минимальный размер заработной платы, установленный законом о республиканском бюджете и действующий на 1 января соответствующего финансового года (1 рубль 6 тенге) и численность работников не превышает 25 человек, включая самого индивидуального предпринимателя и юридические лица, их доход должен составлять 2800-кратный минимальный размер заработной платы, установленный за- коном о республиканском бюджете и действующий на 1 января соответствующего финансового года, а численность работников 50 человек. При применении упрощенной декларации для индивидуального предпринимателя и юридических лиц устанавливается упрощенный порядок исчисления налогов, а именно социальных отчислений, корпоративного и индивидуального подоходного налогов, за исключением налогов, удерживаемых у источника выплаты. Объектом налогообложения является доход за налоговый период, состоящий из всех видов доходов, полученных на территории Республики Казахстан, а также за ее пределами. Налоговым периодом является календарный квартал. Также как и в России для перехода на упрощенный режим нужно подать заявление до начала налогового периода.

Так же, в Казахстане, существует специальный налоговый режим на основе патента. Применяют его только индивидуальный предприниматель. Патент - электронный документ, подтверждающий факт уплаты налогов в бюджет. Патент применяется индивидуальными предпринимателями, не использующими труд наемных работников и фирм, осуществляющих деятельность в форме личного предпринимательства. При этом доход индивидуальных предпринимателей по патенту не должен превышать 300 МЗП. Налоговым периодом является год. Для того, чтобы принять специальный налоговый режим на основе патента нужно рассчитать стоимость патента. В его стоимость включаются подлежащие уплате суммы индивидуального подоходного налога, социальных отчислений. При переходе на систему налогообложения на основе патента нужно подать заявление в налоговый орган до 1 числа месяца применения специального налогового режима. А для только образовавшихся ИП одновременно с подачей заявления о регистрационном учете в качестве индивидуального предпринимателя.

Применение СНР не распространяется на юридические лица, имеющие филиалы и представительства, сами эти филиалы и представительства, подразделения, если учредитель, является учредителем еще одной фирмы, если доля участия других лиц в фирме составляет более $25 \%$ и иные правила прописанные НК.

При переходе на общеустановленный режим, вновь перейти на СНР разрешается только через два года. Индивидуальный предприниматель или юридическое лицо вправе выбрать только 
Таблица 1. Сравнительная таблица ставок по УСН Казахстана и России

\begin{tabular}{|l|l|}
\hline \multicolumn{1}{|c|}{ Казахстан } & \multicolumn{1}{|c|}{ Россия } \\
\hline $\begin{array}{l}\text { 3\% - все доходы, полученные ИП или юридическим } \\
\text { лицом по упрощенной декларации. }\end{array}$ & $6 \%-$ доходы. \\
\hline $2 \%$ - все доходы на основе патента. & $\begin{array}{l}15 \%-\text { доходы, уменьшенные на сумму расходов. } \\
5-15 \% \text { - дифференцированная сумма налога для ИП. }\end{array}$ \\
\hline
\end{tabular}

один специальный налоговый режим.

Как показывает таблица, в Республике Казахстан наиболее льготные ставки применения упрощенной системы налогообложения. Плательщик облагает 3-х\% ставкой весь свой доход по УСН и $2 \%$ по патенту. Согласно Налогового Кодекса РК ст. 436 п. 2 исчисленная по 3\% ставке сумма подлежит корректировке в сторону уменьшения на 1,5\% от суммы налога за каждого работника, исходя их среднесписочной численности работников, если среднемесячная заработная плата работников по итогам отчетного периода составила у индивидуального предпринимателя не менее 2-кратного, юридических лиц - не менее 2,5-кратного минимального размера заработной платы (согласно Закона PK, на 2020 г. МЗП составила - 42500 тенге).

В Российской Федерации, согласно Налогового Кодекса ст. 346.20:

1. В случае, если объектом налогообложения являются доходы, налоговая ставка устанавливается в размере 6 процентов.

2. В случае, если объектом налогообложения являются доходы, уменьшенные на величину расходов, налоговая ставка устанавливается в размере 15 процентов. Законами субъектов Российской Федерации могут быть установлены дифференцированные налоговые ставки в пределах от 5 до 15\% в зависимости от категории налогоплательщиков.

В России в 2013 году вступил в силу закон «О бухгалтерском учете» об изменении бухгалтерского учета индивидуального предпринимателя. Согласно закону все малые предприятия и индивидуальные предприниматели должны вести бухгалтерский учет. Индивидуальные предприниматели, которые платят единый налог на вмененный доход (ЕНВД) должны вести учет всех показателей, которые требуются для исчисления
ЕНВД. Значит, если фирма занимается не единственным видом деятельности, а несколькими, то вести учет придется по каждому из них. От бухгалтерского учета освобождаются предприниматели, которые ведут учет в соответствии с Налоговым Кодексом, а это означает, что те индивидуальные предприниматели, которые применяют упрощенную систему налогообложения могут продолжать вести только учет доходов и расходов, согласно Налоговому Кодексу.

Законом Республики Казахстан «О бухгалтерском учете и финансовой отчетности» определено, что индивидуальные предприниматели, применяющие специальный налоговый режим на основе патента вправе не осуществлять ведение бухгалтерского учета и составления финансовой отчетности [3]. А вот индивидуальные предприниматели, применяющие упрощенную декларацию ведут бухгалтерский учет по своей деятельности в книге учета доходов по установленным формам. Все зависит от того является ли индивидуальный предприниматель плательщиком НДС, что бывает очень редко, и составляют финансовую отчетность в соответствии с указанным стандартом.

Если рассматривать в целом, то в Казахстане более выгодные условия существования УСН, хотя есть и много общего с Россией. Этим двум странам необходимо поддерживать малый и средний бизнес, рассматривать различные льготы для него, направленные на увеличение применения CHР. Упрощенная система налогообложения позволяет развиваться малому и среднему бизнесу как в России, так и в Казахстане. В силу своей гибкости и приспособленности УСН позволяет увеличить занятость населения, снизить безработицу и повысить экономику страны в целом.

\section{Библиографический список}

1. Договор «О дружбе, сотрудничестве и взаимной помощи между Российской Федерацией и Республикой Казахстан» от 25 мая 1992 года (в ред. Протокола от 07.06.2012).

2. Федеральный Закон «Об упрощенной системе налогообложения, учета и отчетности для субъектов малого предпринимательства» от 29 декабря 1995 года. 
3. Закон Республики Казахстан «О бухгалтерском учете и финансовой отчетности» от 28 февраля 2007 года.

4. Налоговый Кодекс Республики Казахстан, Глава 61 «Специальный налоговый режим для субъектов малого бизнеса».

5. Налоговый Кодекс Российской Федерации. Глава 26.2 «Упрощенная система налогообложения». 